\title{
Analysis of the Influence of Communication on Employee Performance Satisfaction with Supervision as a Mediating Variable at Private Contractor Company
}

\author{
Shi Jinqiang \\ Universitas Prima Indonesia, Medan. Indonesia
}

\begin{abstract}
Private project worker organization in Medan declined as of late. Decrease in Representative Fulfillment is brought about by a few things; diminished nature of correspondence and management. The examination tests were drawn by utilizing the immersion recipe comprising of 70 representatives. The halfway testing showed that correspondence has a positive and huge impact on representative fulfillment, wherein the T-count is 4.392 and the worth of T-table is 1.66691 , then, at that point, the worth of T-count> T-table (4.392> 1.66691 ) with huge worth of $0,000>0.05$. The incomplete testing showed that management has a positive and huge impact on worker work fulfillment, in which the worth of oversight variable T-count 2.015> Ttable 1.66691 with an importance worth of $0.005>0.05$. All the while, correspondence and management have a positive and critical impact on worker work fulfillment up to 15,467 in which F-table is 2.74 .
\end{abstract}

Keywords: Communication, Supervision, Employee Job Satisfaction

\section{Introduction}

Alongside the development and advancement of the economy which is progressively fast and hard to anticipate, great HR as of now affect an organization. The accomplishment of an organization in accomplishing its objectives is to a great extent controlled by the human asset factor that can take an interest in its functional exercises. With great $\mathrm{HR}$, the functional exercises run as expected. The main thing is the manner by which to make HR that can give greatest execution results to accomplish organization objectives.

To accomplish the organization's objectives, acceptable correspondence is required between pioneers representatives, just as among representatives and individual collaborators. Between the two gatherings there should be corresponding correspondence, for that there is a requirement for collaboration that is relied upon to accomplish objectives, both individual and gathering objectives, to accomplish the objectives of an association. Likewise, representatives will feel appreciated and perceived for their presentation, they will likewise work more engaged and mix-ups in work will be negligible. The collaboration comprises of different purposes which incorporate social/social relations. The relationship that happens is a course of the presence of a craving of every person, to acquire a genuine outcome and can give advantages to a reasonable life.

To accomplish the organization's objectives, acceptable correspondence is required between pioneers representatives, just as among workers and individual collaborators. Between the two gatherings there should be equal correspondence, for that there is a requirement for participation that is relied upon to accomplish objectives, both individual and gathering objectives, to accomplish the objectives of an association. What's more, representatives will feel appreciated and perceived for their exhibition, they will likewise work more engaged and errors in work will be negligible. The participation comprises of different purposes which incorporate social/social relations. The relationship that happens is a course of the presence of a longing of every person, to get a genuine outcome and can give advantages to a reasonable life.

Occupation fulfillment additionally influences the achievement of the organization. Occupation fulfillment alludes to a singular's positive passionate response to a specific work. To assist with understanding the idea of occupation fulfillment, characterize work fulfillment as a lovely enthusiastic state coming about because of occupation evaluation or professional training. Occupation fulfillment is an assortment of sentiments an 
individual to remain in his work, fortunate or unfortunate, good or negative, which might add to the improvement of sensations of fulfillment or disappointment.

Private worker for hire organization is situated in Medan. Private worker for hire organization has a similar vision and mission as different organizations, specifically to make a benefit for both the organization and its representatives by having great execution so when the exhibition is acceptable, workers will feel fulfilled and obviously they can rival different organizations. Accordingly, organizations are needed to focus fair and square of worker work fulfillment so that representatives feel great and become representatives who have high steadfastness, consequently diminishing the degree of turnover.

\section{Literature Review}

As indicated by Feriyanto and Triana (2015) [1] states that correspondence isn't just significant for people yet in addition significant for the administration control framework is an apparatus that coordinates, rouses, screens or notices and assesses the execution of organization the board that attempts to prompt authoritative objectives inside the organization.

As per Effendi (2015) [2], oversight expresses that size is a circulation of conduct. In the event that the administrator can't gauge, it implies that the director can't regulate or control.

While work fulfillment mirrors one's sentiments towards his work. This can be found in the inspirational perspective of representatives towards their workand all that is looked by their workplace, the staff office or the board should consistently screen work fulfillment since this influences non-appearance, work turnover, work fulfillment and other significant issues [3].

\section{Methodology}

3.1 Examine the relationship between communication, supervision as mediating towards employee job satisfaction.

Ghazali.P.L. et.al, [4], review that an exploration space was figured out how to analyze the connection among correspondence and worker work fulfillment, correspondence and management as intervening, and oversight as interceding towards representative occupation fulfillment in a private worker for hire organization. The surveys were 69 polls which were conveyed in Medan, Indonesia. Respondents were picked among the representative who work at Private Worker for hire Organization, Medan, Indonesia. The poll was embraced from [5] and [6]. The poll has 3 builds, where 1 develop was autonomy variable, 1 develop was interceding variable, and 1 build was reliant variable. By utilizing five Likert-Scale for each question of the survey.

The reacts from respondents for this examination, then, at that point, dissected utilizing Factual Bundles for Sociology (SPSS) form 23 to discover the consequence of dependability investigation, legitimacy investigation and Kolmogrov-Smirnov of the build [7].

\section{Results and Discussions}

\subsection{Reliability-Analysis}

The plan of getting sorted out the research was to dissect the poll's dependability. The following is the aftereffect of unwavering quality investigation for the examination.

Table 1: Reliability Analysis

\begin{tabular}{|l|l|l|}
\hline Variables & Cronbach's-Alpha & No. of Item \\
\hline Communication & 0.962 & 10 \\
\hline Employee Job Satisfaction & 0.911 & 10 \\
\hline Supervision & 0.967 & 10 \\
\hline
\end{tabular}

It shown that all of the three factors got high Cronbach's-alpha, the Cronbach's-alpha is greater than 0.6 means acknowledged [8]. 


\subsection{Validity (F-Test and T-Test)}

As indicated by Ghozali (2015) [9] F-test and T-test essentially shows how far the impact of one informative/free factor separately in clarifying the variety of the reliant variable.

Table 2: F-test

ANOVA ${ }^{\text {a }}$
\begin{tabular}{|l|l|l|l|l|l|l|}
\hline Model & $\begin{array}{l}\text { Sum of df } \\
\text { Squares }\end{array}$ & $\begin{array}{l}\text { Mean } \\
\text { Square }\end{array}$ & F & Sig. \\
\hline \multirow{3}{*}{1} & $\begin{array}{l}\text { Regressi } \\
\text { on }\end{array}$ & 289.504 & 2 & 144.752 & 14.889 & $.001^{\mathrm{b}}$ \\
\cline { 2 - 8 } & Residual & 641.655 & 66 & 9.722 & & \\
\cline { 2 - 8 } & Total & 931.159 & 68 & & & \\
\hline
\end{tabular}

a. Dependent Variable: Kinerja

b. Predictors: (Constant), Komunikasi, Pengawasan

Table 3: T-test

\begin{tabular}{|c|c|c|c|c|c|}
\hline \multicolumn{6}{|l|}{ Coefficients $^{\mathrm{a}}$} \\
\hline \multirow[t]{2}{*}{ Model } & \multicolumn{2}{|c|}{$\begin{array}{l}\text { Unstandardized } \\
\text { Coefficients }\end{array}$} & \multirow{2}{*}{\begin{tabular}{|l|}
$\begin{array}{l}\text { Standar } \\
\text { dized } \\
\text { Coeffici } \\
\text { ents }\end{array}$ \\
Beta \\
\end{tabular}} & & \multirow[t]{2}{*}{ Sig. } \\
\hline & $B$ & Std. Error & & & \\
\hline $\begin{array}{l}\text { Consta } \\
\text { nt })\end{array}$ & 4.882 & 3.537 & & 1.380 & 172 \\
\hline $\begin{array}{l}\text { Kompet } \\
\text { ensi }\end{array}$ & .443 & .104 & .4554 & 4.252 & .000 \\
\hline $\begin{array}{l}\text { Pelatiha } \\
n\end{array}$ & .238 & .112 & .219 & 2.048 & .045 \\
\hline Dependent & Varia & e: Kinerja & & & \\
\hline
\end{tabular}

From the table 2 and table 3 over, the outcome shows that the legitimacy are substantial. It implies that the theory were acknowledged.

\subsection{Normality Test}

Normality test was overseen as its prerequisite [10]. By utilizing one-example Kolmogorov-Smirnov test [11], it shows that the gathered information were circulated typically. Table 4 beneath shows the outcome.

Table 4: Statistical Normality Test

One-Sample Kolmogorov-Smirnov Test

\begin{tabular}{|ll|l|}
\hline & & $\begin{array}{l}\text { Unstandardized } \\
\text { Residual }\end{array}$ \\
\hline $\mathrm{N}$ & Mean. & 69 \\
Normal Parameters & $\mathrm{a}, \mathrm{b}$ & .0000000 \\
& Std. Deviation. & 4.44056836 \\
& Absolute. & .090 \\
Most Extreme Differences & Positive. & .086 \\
& Negative. & -.090 \\
Kolmogorov-Smirnov Z & & .901 \\
Asymp. Sig. (2-tailed) & & $\mathbf{3 9 2}$ \\
\hline
\end{tabular}

a. Test distribution is Normal.

b. Calculated from data. 
The $\mathrm{p}$-value $=>0.05$ on the one-example Kolmogrov-Smirnov test insights yield on Table 4 above shows that the information gathered abuse the suspicion of ordinariness dispersion. Because of the infringement of ordinariness dispersion, it proposed to utilize parametric procedure investigation [10].

\section{Conclusion}

From the unwavering quality test outcome, It shown that all of the three factors got high Cronbach's-alpha, the Cronbach's-alpha is greater than 0.6 means acknowledged [11]. With the goal that the embraced instruments to the populace and circumstance of the exploration were acknowledged. From the F-test and T-test, the outcome From the ordinariness test by utilizing 0ne-example Kolmogrov-Smirnov test, the outcome show that the gathered information were regularly conveyed.

\section{References}

1. Feriyanto, Triana dan Endang Shyta. (2015). "Pengantar Manajemen". Yogyakarta: Mediatera.

2. Effendi, (2015). "Pengantar Manajemen: Character Inside", Jakarta: Kita Menulis. SAMPAI SINI

3. Sunyoto, Danang. 2018. Penelitian Sumber Daya Manusia. Cetakan pertama. Yogyakarta Center Academic Publishing Service.

4. Ghazali, P.L, I. Mohd, W.M.A.W. Ahmad and M. Mamat, 2012. Integration Model of Education Plan Takaful: A Case Study for Terengganu, Kelantan and Perlis, States in Malaysia . Far East Journal of Mathematical Sciences (FJMS). Alahabad, India. Puspha Publishing House, Volume 65 No.1 (2012). Issue of the FJMS: 97-117.

5. Handoko, Hani. 2012. "Manajemen Personalia dan Sumber Daya Manusia”. Cetakan keduapuluh satu. Yogyakarta BPFE.

6. Mangkunegara, Prabu, Anwar. 2017. Manajemen Sumber Daya Manusia Perusahaan. Cetakan keduabelas. Bandung : PT. Remaja Rosdakarya.

7. Torang, Syamsir. 2012. Metode Riset Struktur dan Perilaku Organisasi. Bandung Alfabeta.

8. Sekaran, U and Bougie. R, Research methods for business: A skill building approach. John Wiley \& Sons, 2006.

9. Ghozali, Imam. 2015. “Aplikasi Analisis Multivariete Dengan Program SPSS 23”. Semarang: Badan Penerbit Universitas Diponegoro.

10. Ghasemi, A \& Zahediasl, S, Normality tests for statistical analysis: A guide for non-statisticians. International Journal of Endocrinology and Metabolism, (2012) 10(2), 486-489.

11. Pallant, J, SPSS survival manual: A step-by-step guide to data analysis using SPSS version 15 . Nova Iorque: McGraw Hill. 2007. 